\title{
The effect of density on sea bass (Dicentrarchus labrax) performance in a tank-based recirculating system
}

\author{
Sophie Sammouth ${ }^{\mathrm{a}}$, Emmanuelle Roque d'Orbcastel ${ }^{\mathrm{a}}$, Eric Gasset ${ }^{\mathrm{a}}$, Gilles Lemarié ${ }^{\mathrm{a}}$, Gilles \\ Breuil $^{a}$, Giovanna Marino ${ }^{b}$, Jean-Luc Coeurdacier ${ }^{a}$, Sveinung Fivelstad ${ }^{c}$ and Jean-Paul \\ Blancheton ${ }^{\mathrm{a}, *}$
}

\footnotetext{
${ }^{a}$ Ifremer, Chemin de Maguelone, 34250 Palavas-les-Flots, France

b ICRAM, Aquaculture Unit, Via Casalotti 300, Rome 00166, Italy

${ }^{\mathrm{c}}$ Bergen University College, Bergen, Norway
}

*: Corresponding author : Jean-Paul Blancheton, email address : jean.paul.blancheton@ifremer.fr

\begin{abstract}
:
Sea bass (Dicentrarchus labrax) (135 $\pm 4 \mathrm{~g}$ ) were reared under tank-based recirculating aquaculture system for a 63-day period at four densities: 10, 40,70, $100 \mathrm{~kg} \mathrm{~m}^{-3}$. Fish performance, stress indicators (plasma cortisol, proteonemia plus other blood parameters- $\mathrm{Na}^{+}, \mathrm{K}^{+}$, glucose, $\mathrm{pH}$, total $\mathrm{CO}_{2}{ }^{-}$) and water quality were monitored. At the end of the 63-day period, resistance to infection was also studied by a nodavirus challenge. A 25-day test was performed on fish from two extreme densities $\left(10\right.$ and $\left.100 \mathrm{~kg} \mathrm{~m}^{3}\right)$ and one intermediate density $\left(40 \mathrm{~kg} \mathrm{~m}^{3}\right)$.

With regards to the different density treatments, there was no significant difference between the daily feed intake (DFI) and the specific growth rate (SGR) up to a density of $70 \mathrm{~kg} \mathrm{~m}^{-3}$. No significant difference was found between treatments concerning the feed conversion ratio (FCR) and the mortality rate. No density effect was observed on the fish stress level (plasma cortisol) or on sensitivity to the nodavirus challenge. Under these experimental rearing conditions, the density above $70 \mathrm{~kg} \mathrm{~m}^{-3}$ has an impact on growth performance (DFI and SGR) indicators and also some blood parameters $\left(\mathrm{CO}_{2}\right)$ at the highest density tested $\left(100 \mathrm{~kg} \mathrm{~m}^{-3}\right)$.
\end{abstract}

This study suggests that a density up to $70 \mathrm{~kg} \mathrm{~m}^{-3}$ has no influence on sea bass performance and welfare. At $100 \mathrm{~kg} \mathrm{~m}^{-3}$, average specific growth rate was decreased by $14 \%$ without welfare deterioration according to the welfare indicators monitored.

Keywords: Density; Recirculating system; European sea bass; Performance; Welfare 


\section{Introduction}

Today, consumer demand for safe and ethically defendable food products is very much on the increase. Production systems must consider animal well-being and good health. Those factors depend on proper care and good husbandry practices. With regards to aquaculture, recirculating production systems are often associated to high density in tanks. Previous studies analysed the effect of increasing density on biological performance in fish, with positive and negative impacts observed according to the species (Irwin et al., 1999). Generally speaking, high density is considered as a potential source of stress, with a negative effect on fish growth rate (Lefrançois et al., 2001) and survival and feeding rates (Rowland et al., 2006). Daily feed intake and specific growth rate decreases were observed at increasing density levels on several species such as Atlantic cod (Gadus morhua L.) (Lambert and Dutil, 2001), brook charr (Salvelinus fontinalis) (Vijayan and Leatherland, 1988), gilthead sea-bream (Sparus aurata) (Canario et al., 1998) and largemouth bass (Micropterus salmoïdes) (Petit et al., 2001). Negative effects of high density on fish performance are generally associated to water quality deterioration or/and increase of aggressive behaviour (Ellis et al., 2002).

Most of the studies on the impact of density on fish performance have been carried out with freshwater species, mainly salmonids. Little information is available for marine species (Turnbull et al., 2005). Studies were carried out on Atlantic halibut (Hippoglossus hippoglossus) (Kristiansen et al., 2004), Dover sole (Solea solea) (Schram et al., 2005), Atlantic salmon (Salmo salar) (Irwin et al., 1999), gilthead sea-bream (Sparus aurata) (Canario et al., 1998) but few on European sea bass (Dicentrarchus labrax) (Roncarati et al., 2006). Sea bass is one of the leading Mediterranean cultivated species (Papoutsoglou et al., 1998) and is classically produced in cages. In view of difficult accessibility of coastal areas due to competition with other activities, recirculating aquaculture systems (RAS), which require less space, represent an important alternative to marine fish production in cages. In the present context of water resource deterioration, RAS also present an opportunity to reduce water consumption and effluent emission by a factor of 100 in comparison to classical flow through systems (Blancheton, 2000) and allow concomitant control of rearing water quality. But little information is available on the effect of density on fish performance under intensive RAS conditions (Chandroo et al., 2004). In sea bass, no differences in growth, survival, plasma cortisol glucose, total proteins, triglycerides and cholesterol were observed in fish reared in recirculating tanks at different densities up to $45 \mathrm{~kg} \mathrm{~m}^{-3}$ (Di Marco et al., 2008).

Classical performance parameters, such as growth and survival rates (Jørgensen et al., 1993; Canario et al., 1998; Papoutsoglou et al., 1998; Irwin et al., 1999; Sørum and Damsgård, 2004) and blood parameters, such as plasma cortisol and glucose level (Kjartansson et al., 1988; Mazur and Iwama, 1993; Montero et al., 1999), can be used to measure the potential effect of density on fish performance and welfare. An alteration of serum protein concentration (proteinemia) has been also reported in relation to stress conditions in some species (Jeney et al., 1997; Coeurdacier and Dutto, 1999; Magnadóttir et al., 1999).

The aim of the present study was to assess the effect of density on sea bass performance, stress and resistance to infection in a recirculating system. This study was part of the Wealth Project (Welfare and health in sustainable aquaculture), that associated European researchers and farmers from 2004 to 2007, to define objective health and wellbeing criteria for aquaculture. Large range of densities are commonly applied in European farms, from 10 to more than $100 \mathrm{~kg} \mathrm{~m}^{-3}$, according to the rearing system, the fish species and size (Ellis et al., 2002). During the 88 day experiment, fish performance, stress and resistance to infection were monitored at four different stabilized densities: 10, 40, 70 or $100 \mathrm{~kg} \mathrm{~m}^{-3}$. 


\section{Materials and methods}

\subsection{Fish management and feeding}

\subsubsection{The acclimatization phase}

Sea bass were supplied by Méditerranée Pisciculture (Salses-le-Château, France), a partner farm for the Wealth project. Fish were stored for 2 months at $70 \mathrm{~kg} \mathrm{~m}^{-3}$ in a circular tank. During this phase of acclimatization to the RAS conditions and the tank design, fish were fed at $1.5 \%$ of biomass per day. They were also treated with Tugon 80 against a branchial parasite Diplectanum aequans (dose of $0.5 \mathrm{~g} \mathrm{~m}^{-3}$ during 48 hours).

\subsubsection{The 63 day experiment}

Fish (mean body weight $135 \pm 4 \mathrm{~g}$ S.D.) were starved for $24 \mathrm{~h}$, anaesthetized with 2phenoxyethanol and then sorted for allocation to experimental tanks randomly. During 63 days, the fish were held in separate tanks at four different densities: 10, 40, 70 and $100 \mathrm{~kg}$ $\mathrm{m}^{-3}$. The experiment was divided into 3 periods of 21 days each (called P1, P2 and P3) to adjust tank densities at the end of each period by biomass random removal. Fish were manually fed, ad libitum, once a day (in the morning). Three criteria were used to assess satiation: (1) indifference of the fish for pellets, (2) first uneaten pellets on the tank bottom and (3) first pellets collected in the particle trap of each tank. Uneaten pellets collected in the particle traps were counted after each meal. The extruded commercial feed (Neo Grower Extra Marin, Le Gouessant) was composed of $45 \%$ of proteins and $20 \%$ of lipids, and presented a digestible energy of $18.5 \mathrm{MJ}$ per $\mathrm{kg}_{\text {of }} \mathrm{feed}^{-1}$.

\subsubsection{The Nodavirus challenge}

At the end of the 63 day experiment, a challenge test was performed during 25 days on the fish from 3 different densities: two extreme densities (10 and $100 \mathrm{~kg} \mathrm{~m}^{-3}$ ) and an intermediate density $\left(40 \mathrm{~kg} \mathrm{~m}^{-3}\right)$, corresponding to an usual density in commercial systems.

Fish were inoculated (intramuscular inoculation) with $0.2 \mathrm{ml}$ of live Nodavirus suspension SW80 ( $9 * 10^{5}$ PFU per fish) as described by Coeurdacier et al. (2003). Thirty fish from each density treatment were placed in triplicate tanks $\left(1 \mathrm{~m}^{3}\right)$. The tanks were connected to the same RAS and water temperature was maintained at $25^{\circ} \mathrm{C}$. As a control, 30 fish from each density treatment were inoculated with sterile $0.5 \% \mathrm{NaCl}$ solution. The tank used for the control group was connected to a separate RAS to avoid Nodavirus contamination. Total morbidity (i.e. mortalities and fish showing abnormal swimming behaviour) was recorded daily.

\subsection{Experimental design}

The experimental facility was composed of 12 circular tanks ( $1 \mathrm{~m}^{3}$ each) all working in RAS. The fish population was divided on the basis of four density treatments, 10, 40, 70 and $100 \mathrm{~kg} \mathrm{~m}^{-3}$ with each density treatment randomly allocated to triplicate tanks.

The experimental RAS was fed with pumped sea water and three water loops were used in order to optimise water management. The first loop generated water circulation with a pump system, the second loop produced super-oxygenated water (at $25 \mathrm{mg} \mathrm{l}^{-1}$ ) due to a cone system and the third was the treatment loop described by Blancheton (2000). Thanks to the treatment loop, the same water quality was maintained in tanks independently of the density. This treatment loop including the $\mathrm{CO}_{2}$ degassing column, mechanical, biological and UV filters, was designed to keep the rearing water quality below the recommended values for aquaculture (Pierce et al., 1993; Person Le Ruyet et al., 1997; Colt, 2006). 
The $\mathrm{pH}$ was controlled using soda addition to keep values around 7.0-7.4 (Fivelstad et al., 1995; 1998). Water temperature was maintained at the optimal level for growth at around $24^{\circ} \mathrm{C}$ (Person-Le Ruyet et al., 2004) using a heat exchanger. Make up water was filtered twice $(40 \mu \mathrm{m}$ and $15 \mu \mathrm{m})$ before use. Tank water flows were measured and adjusted before the experiment in order to be proportional to the fish density per tank (Table 1). It was necessary to double the water flow rate per $\mathrm{kg}$ of biomass in the triplicate $10 \mathrm{~kg} \mathrm{~m}^{-3}$ tank to ensure sufficient water circulation and avoid faeces settling in the tanks.

\subsection{Measured parameters}

\subsubsection{Water quality parameters}

Temperature and salinity were measured daily in all tanks, with a Checktemp1 pocket Thermometer (Hanna instruments) and an ATAGO hand refractometer S/Mill-E. The $\mathrm{pH}$ and oxygen were also measured every day in all tanks using an Ecoscan ${ }^{\circ} \mathrm{pH}$ meter and a YSI 550A oxymeter. Oxygen concentration was monitored using Oxyguard $®$ probes connected to a computerized measuring system (Linde soft). Carbon dioxide concentration was measured in samples once a week using a calibrated non-dispersive infrared (NDIR) gas analyzer ( $\mathrm{Li}$-cor $\mathrm{CO}_{2}$ analyser).

Water samples were taken during the post-prandial period (when the excretion by the fish was maximal) and stored after filtration until analysis in appropriate conditions (preserved with chloroform and stored at $4^{\circ} \mathrm{C}$ or frozen before analysis). Analyses were performed in the station's lab on the same day or the day after. Suspended solids (SS) concentrations were determined after filtration on the GF/C porous membrane and dissolved elements measured by spectrophotometry. Total ammonia nitrogen (TAN), nitrite-nitrogen $\left(\mathrm{NO}_{2}-\mathrm{N}\right)$, and orthophosphates $\left(\mathrm{PO}_{4}-\mathrm{P}\right)$ were analysed using an Alliance Instruments Evolution II. $\mathrm{NO}_{3}-\mathrm{N}$ was measured with a Technicon ${ }^{\circledR}$ Autoanalyzer II. Tank water flows were measured with electronic flow-meters (Flo-Mate, Marsh-MCBirney, model 2000).

\subsubsection{Fish performance parameters}

Fish mortality was counted daily. At the end of each period (P1, P2, P3), biometrics were carried out in order to adjust the biomass in the tank according to the 4 studied densities. Before biometrics, fish were anaesthetized in their tank (2-phenoxyethanol, $220 \mathrm{ppm} \mathrm{m}^{-3}$ ). All the tank biomass was weighed and any fish in excess were removed. Fish were taken randomly and weighed $(\mathrm{W}, \mathrm{g})$ and measured at the caudal fin fork $(\mathrm{L}, \mathrm{mm})$. Performance was calculated using the following indicators:
(1) Daily feed intake (DFI \%)
$(F / n) /\left(\left(B_{f}+B_{i}\right) / 2\right) * 100$
(2) Feed conversion ratio (FCR) =
$F /\left(B_{f}-B_{i}\right)$
(3) Specific growth rate $\left(\right.$ SGR $\left.\% d^{-1}\right)=$
$\left(\mathrm{Ln} \mathrm{W}_{\mathrm{f}}-\mathrm{Ln} \mathrm{W}_{\mathrm{i}}\right) * 100 / \mathrm{n}$

where: $\mathrm{F}=$ Feed consumption per period $(\mathrm{g}), \mathrm{n}=$ number of days in a period, $\mathrm{B}_{\mathrm{f}}=$ final biomass $(\mathrm{g}), \mathrm{B}_{\mathrm{i}}=$ initial biomass $(\mathrm{g}), \mathrm{W}_{\mathrm{i}, \mathrm{f}}=$ initial and final body average weight $(\mathrm{g})$ over a period.

\subsubsection{Blood parameters}

Cortisolemia was measured on fish held at three densities: two extreme densities (10 and $100 \mathrm{~kg} \mathrm{~m}^{-3}$ ) and an intermediate density $\left(40 \mathrm{~kg} \mathrm{~m}^{-3}\right)$. Blood was taken from the caudal vein of 10 fish (starved $24 \mathrm{~h}$ before sampling), anaesthetized for $3 \mathrm{~min}$ at $4^{\circ} \mathrm{C}$ seawater. Blood samples were taken within 8 min of fish capture to minimize handling stress. Serum was separated by centrifugation ( $\left.15000 \mathrm{tpm}, 5 \mathrm{~min}, 4^{\circ} \mathrm{C}\right)$ and stored at $-20^{\circ} \mathrm{C}$ until analysis. Cortisol was measured using commercially available solid phase 125lodine RIA measuring the total amount of hormone in unextracted serum (Coat-A-Count Cortisol ${ }^{\circledR}$, D.P.C. Los Angeles, CA). The sensitivity of the assay was $2 \mathrm{ng} \mathrm{m}^{-1}$ and the intra-assay and the inter-assay coefficients of variation were 4.7 and $6.4(n=3)$, respectively. Data was obtained with a Kontron Analytical MDA 312 and analyzed using RIA software. 
Proteinemia was measured on fish held at three different densities $\left(10,40\right.$ and $100 \mathrm{~kg} \mathrm{~m}^{-}$ $\left.{ }^{3}\right)$. Proteinemia was determined with an auto analyser Max Mat Hycel, based on principle of the Biuret reaction. Bovine serum albumin was used as standard and data expressed in $\mathrm{mg} \mathrm{ml}^{-1}$. Samples for cortisolemia and proteinemia were taken at the end of the experiment and at days 21 and 42 respectively.

Other blood parameters including sodium $\left(\mathrm{Na}^{+}\right)$, potassium $\left(\mathrm{K}^{+}\right)$, partial pressure of $\mathrm{CO}_{2}$ $\left(\mathrm{pCO}_{2}\right)$, Total $\mathrm{CO}_{2}\left(\mathrm{HCO}_{3}{ }^{-}+\right.$dissolved $\left.\mathrm{CO}_{2}+\mathrm{H}_{2} \mathrm{CO}_{3}\right)$, glucose, haematocrit $(\mathrm{Hct})$ and haemoglobin $(\mathrm{Hb})$ were measured on fish held at three densities $\left(10,40\right.$ and $\left.100 \mathrm{~kg} \mathrm{~m}^{-3}\right)$ at day 63 (end of the third period P3). Blood was sampled with heparinized syringes in the caudal vein of 5 fish per condition and in triplicate (total of 45 fish). Measurements were obtained using an Abbott i-STAT analyser (Abbot Norge AS, N-1361 Billingstad, Norway) using EC8+ cartridges corrected when necessary in relation to the temperature.

\subsection{Data analysis}

Statistical analyses were performed using Statistica 5.5 1999. Data normality and variance homogeneity (Hartley tests) were assessed. Performance indicators (DFI, FCR and SGR), fish length, water quality and proteinemia were subjected to a one-way ANOVA with one fixed factor (density). Cortisol data were subjected to a two-way ANOVA to determine the combined effects of density and time.

\section{Results}

\subsection{Water quality}

The daily water renewal rate was 91,68 and $67 \%$ for the first, second and third periods respectively, corresponding to $3,2.3$ and $2.2 \mathrm{~m}^{3}$ of make up water per $\mathrm{kg}$ of feed.

Average water salinity, dependant on the daily supply of seawater, was $37.2 \pm 1.8 \%$ o during the 63 day experiment. The temperature was stable around $23.4 \pm 0.98^{\circ} \mathrm{C}$. Oxygen concentration was above saturation for all treatments, $114.4 \pm 24.9 \%$.

The $\mathrm{pH}$ was significantly different for the $10 \mathrm{~kg} \mathrm{~m}^{-3}$ treatment compared to the other fish loads $(P<0.001)$, with an average $\mathrm{pH}$ recorded at $3 \%$ higher for the $10 \mathrm{~kg} \mathrm{~m}^{-3}$ condition. The $\mathrm{CO}_{2}$ concentration was significantly different between the 4 treatments $(P<0.001)$ being $78 \%$ higher at $40 \mathrm{~kg} \mathrm{~m}^{-3}$ than at $10 \mathrm{~kg} \mathrm{~m}^{-3}$. However, $\mathrm{CO}_{2}$ concentrations never exceeded $20 \mathrm{mg} \mathrm{1}^{-1}$.

$\mathrm{SS}, \mathrm{TAN}, \mathrm{NO}_{2}-\mathrm{N}$ and $\mathrm{NO}_{3}-\mathrm{N}$ concentrations remained under $60 \mathrm{mg} \mathrm{l}^{-1}, 2 \mathrm{mg} \mathrm{l}^{-1}, 2 \mathrm{mg} \mathrm{l}^{-1}$ and $100 \mathrm{mg} \mathrm{l}^{-1}$ respectively as recommended by Blancheton (2000). Water quality characteristics are detailed in Table 2. A significant difference between the 4 treatments was observed for TAN $(P<0.001)$ and $\mathrm{NO}_{2}-\mathrm{N}(P<0.001)$ concentrations. The TAN concentrations in 40,70 and $100 \mathrm{~kg} \mathrm{~m}^{-3}$ tanks were significantly higher (47\%) than those maintained at $10 \mathrm{~kg} \mathrm{~m}^{-3}$ and $\mathrm{NO}_{2}-\mathrm{N}$ concentration was $5 \%$ lower. There was no significant difference in the $\mathrm{NO}_{3}-\mathrm{N}(P=0.253)$ and $\mathrm{PO}_{4}-\mathrm{P}(P=0.269)$ concentrations between all the treatments.

\subsection{Fish performance}

\subsubsection{Biological performance}

The survival rate was $99 \%$ independently of the density and the period. Half of the mortality observed was due to fish jumping out of tanks. No aggressive behaviour was observed at the different densities tested in the RAS.

The effect of density on the DFI was significant $(P=0.031)$. Up to $70 \mathrm{~kg} \mathrm{~m}^{-3}$ treatment, the DFI was $8 \%$ higher than the DFI at $100 \mathrm{~kg} \mathrm{~m}^{-3}$ (Fig. 1). At the end of the 63 day 
experiment the DFI of all treatments was improved by $7 \%$. No significant difference in the FCR $(P=0.154)$ was observed between the 4 treatments (Fig.1). The FCR improved with time for all the groups ranging from 2.37 at the beginning of the experiment to 1.68 at day 63.

The SGR was $0.81 \% \mathrm{~d}^{-1}$ for the 10,40 and $70 \mathrm{~kg} \mathrm{~m}^{-3}$ treatments. It was significantly lower $(P<0.05)$ at $100 \mathrm{~kg} \mathrm{~m}^{-3}$, with $0.71 \% \mathrm{~d}^{-1}$ corresponding to a $14 \%$ of decrease (Fig. 1$)$. The SGR increased significantly between P1 and P2 and decreased in P3 for all the density treatments (Fig. 2). Fish weight increased from $135 \pm 4 \mathrm{~g}$ to $226 \pm 35 \mathrm{~g}$ for the 10, 40 and $70 \mathrm{~kg} \mathrm{~m}^{-3}$ treatments and up to $212 \pm 34 \mathrm{~g}$ for the $100 \mathrm{~kg} \mathrm{~m}^{-3}$ treatment.

No significant difference was detected between lengths of fish reared at the 4 different treatments at any period (data not shown).

\subsubsection{Resistance to infectious challenge}

The nodavirus challenge revealed no significant difference $(P<0.05)$ between treatments (ie initial densities). Mean morbidity ranged from 65 to $72 \%$ (Fig. 3) and the nodavirus was detected by ELISA in the brain of 5 affected fish from each tank, according to Varsamos et al. (2006). Neither morbidity nor mortality was observed in the control group inoculated with sterile supernatant culture cells (data not shown).

\subsection{Blood parameter results}

\subsubsection{Cortisol level}

No significant difference $(P=0.71)$ (Fig. 4) was identified in the plasma cortisol of the fish reared at the different density treatments $\left(10,40\right.$ and $\left.100 \mathrm{~kg} \mathrm{~m}^{-3}\right)$. No change occurs over time $(P=0.93)$ or as an effect of interaction of time and density $(P=0.96)$. No significant difference was found within either density treatment or between treatments throughout the confinement period.

\subsubsection{Proteinemia}

At the end of $\mathrm{P} 2$, there was no significant difference between proteinemia of the 3 density treatments (Fig. 5), with a tendency of a higher protein concentrations for fish reared at 10 $\mathrm{kg} \mathrm{m}^{-3}$. At the end of the experiment, the proteinemia concentration of the fish reared at 10 $\mathrm{kg} \mathrm{m}^{-3}$ was significantly lower than at the other densities. However, the values always remained into the range of $38-44 \mathrm{mg} \mathrm{ml}^{-1}$.

\subsubsection{Other blood parameters}

Blood parameter measured in fish kept at 10,40 and $100 \mathrm{~kg} \mathrm{~m}^{-3}$ at the end of the 63 day experiment are presented in Table 3.

Excepting the $\mathrm{TCO}_{2}$ and associated components $\left(\mathrm{PCO}_{2}\right.$ and $\left.\mathrm{HCO}_{3}\right)$, there was no significant difference between the other blood parameters of the 3 treatment groups. The $\mathrm{TCO}_{2}$ and associated components were significantly lower in the blood of fish reared under the $10 \mathrm{~kg} \mathrm{~m}^{-3}$ treatment.

\section{Discussion}

During the whole experiment, the values of the water quality key parameters were kept close to the recommended values for sea bass aquaculture in all the density treatments (Pierce et al., 1993; Person Le Ruyet et al., 1997; Colt, 2006). Neither $\mathrm{CO}_{2}$ nor TAN were above critical levels and $\mathrm{O}_{2}$ concentration was always above saturation (Lemarié et al., 
2004). The average temperature was close to the optimum i.e. $24^{\circ} \mathrm{C}$ (Person-Le Ruyet et al., 2004) and the $\mathrm{pH}$ was optimal.

There was no impact of density on fish mortality ( $1 \%$ mortality for each treatment). Density had no effect on the feed conversion ratio either contrary to the results in previous studies (Vijayan and Leatherland, 1988; Papoutsoglou et al., 1998). The average FCR was high (2.37) at the beginning of the experiment, probably due to multiple fish handling and improved (1.68) through to the end of the study. There was no significant difference in the lengths of fish groups reared at different densities.

Up to $70 \mathrm{~kg} \mathrm{~m}^{-3}$, there was no effect of density on the daily feed intake (DFI) and on the specific growth rate (SGR). At the highest density tested $\left(100 \mathrm{~kg} \mathrm{~m}^{-3}\right)$, the DFI was significantly lower (8\%) than for the other treatments as was the SGR (14\%). FCR was therefore higher at the highest density although not significant. Previous studies (Baker and Aylers, 1990; Pickering, 1992; Alanärä and Brännäs, 1996) revealed a correlation between the density increase and the feed intake decrease due to a stress suffered by the fish. Reduction of DFI can also be observed at low densities due to hierarchical feeding behaviour establishment (Wallace et al., 1988; Jorgensen et al., 1993; Zoccarato et al., 1994). In our study, no aggressive behaviour was observed at different densities, even during feeding time, suggesting no hierarchical feeding behaviour being established as the density was increased. The lower SGR observed on fish reared at $100 \mathrm{~kg} \mathrm{~m}^{-3}$ is due to a DFI decrease related to the density. An additional reduced growth may be due to an increased metabolic demand, as suggested by Di Marco et al. (2008), who report an increase in serum nonesterified fatty acid concentration and the mobilization of lipid reserves in sea bass at high density.

The DFI increased slightly during the experiment $(+7 \%)$, but remained lower than the DFI given by the food manufacturer $\left(1.6 \%\right.$ at $23^{\circ} \mathrm{C}$ and $1.7 \%$ at $\left.25^{\circ} \mathrm{C}\right)$, as often observed under laboratory conditions (Di Marco et al., 2008). One may consider there was an acclimatisation phase, where the fish get used to their new environment and to management conditions.

The nodavirus challenge revealed no significant difference between the 10,40 and $100 \mathrm{~kg}$ $\mathrm{m}^{-3}$ treatments. Resistance to infection was similar independently of the density.

With regards to cortisol response to density, no significant difference was observed between in fish kept at 10, 40 and $100 \mathrm{~kg} \mathrm{~m}^{-3}$. Similar results were reported in sea bass reared 45 days at densities up to $21 \mathrm{~kg} \mathrm{~m}^{-3}$ (Di Marco et al., 2003) and $45 \mathrm{~kg} \mathrm{~m}^{-3}$ (Marino et al., 2004); mean cortisol level did not change after 2 and 6 weeks in sea bass stocked at 15,30 and $45 \mathrm{~kg} \mathrm{~m}^{-3}$ (Di Marco et al., 2008) even if short-term cortisol response to an acute challenge, e.g. crowding was higher at the highest density. The mean plasma cortisol level measured in our study in the different stocking density groups (33-52 $\mathrm{ng} \mathrm{ml}^{-1}$ ) was similar to cortisol levels reported by Marino et al. (2001) and by Di Marco et al. (2008). In other studies, extended periods of confinement at high density levels induced elevation of plasma cortisol in fish species such as salmonids (Pickering et al., 1989; Mazur and Iwama, 1993), sea bream (Barton et al., 2005) and ayu (Plecoglossus altivelis) (Iguchi et al., 2003). Such discrepancies could be related to fish species and to experimental factors other than density, such as water quality variation (Ellis et al. , 2002). In our experiment, water quality was kept close to the recommended values for sea bass and was similar in all the density treatments.

Growth reduction is generally considered to be a good indicator of chronic stress and in some species density acts as a chronic stressor eliciting a sustained increase in plasma cortisol (Wedemeyer, 1997; Wendelaar Bonga, 1997; Procarione et al., 1999). In our experiment, despite the decreased growth rate of sea bass reared at $100 \mathrm{~kg} \mathrm{~m}^{-3}$ from P2 onwards, no plasma cortisol increase was measured in the $100 \mathrm{~kg} \mathrm{~m}^{-3}$ treatment at the end of P3, indicating that reduction in growth rate observed at the highest stocking density cannot be directly explained by a mechanism involving chronic cortisol release. This study provides evidence that rearing density up to $100 \mathrm{~kg} \mathrm{~m}^{-3}$ is probably not a chronic stress factor for sea bass and does not result in significant changes in cortisol response. Alternatively, the lack of difference in plasma cortisol levels could reflect an 
acclimatisation process to density-induced stress (by increasing cortisol turnover, cortisol deposition in the liver and/or exhaustion of inter-renal tissue) from day 21 onwards. Even if this possibility cannot be excluded, recent findings (Rotlant et al., 2003) indicated that the inter-renal tissue of sea bass has a high degree of activity (higher than other species, e.g. sea bream) together with high adrenocorticotropic hormone (ACTH) sensitivity, which is not lost after acute confinement stress at $70 \mathrm{~kg} \mathrm{~m}^{-3}$. The lack of significant differences in cortisol levels suggests, however, that if an acclimation process occurred it was not density-dependent, as observed in salmonids (Jorgensen et al., 1993; Procarione et al., 1999).

There was no significant difference between the $\mathrm{Na}, \mathrm{K}$, glucose, $\mathrm{pH}$ and haematocrit blood levels of the 3 density treatments followed $\left(10,40\right.$ and $\left.100 \mathrm{~kg} \mathrm{~m}^{-3}\right)$, but the $\mathrm{CO}_{2}$ levels were significantly lower at $10 \mathrm{~kg} \mathrm{~m}^{-3}$. Schreck et al. (1997) observed an increase of swimming activity up to $60 \%$ higher with density increase. During this experiment, the swimming activity did not increase at $100 \mathrm{~kg} \mathrm{~m}^{-3}$, but the fish were more restless (Bégout, pers. comm.). This behaviour observed for the $100 \mathrm{~kg} \mathrm{~m}^{-3}$ treatment could explain the $\mathrm{CO}_{2}$ blood levels increase.

From the middle to the end of the experiment, these proteinemia values (38-44 mg ml${ }^{-1}$ ) remained in the range of standard concentrations for fish (Roche and Bogé, 2000; Bayir et al., 2007). These results are in accordance with the haematocrit levels which were similar for the 3 treatments at the end of the experiment. Consequently, the results cannot conclusively be considered as bearing any relation between physiological stress indicators and density in sea bass.

\section{Conclusion}

This study demonstrated, under experimental conditions and controlled water quality, that sea bass can be reared in a recirculating aquaculture system up to $70 \mathrm{~kg} \mathrm{~m}^{-3}$ without performance and welfare degradation. Daily feed intake and specific growth rate decrease at $100 \mathrm{~kg} \mathrm{~m}^{-3}$ probably due to an increase in the fish agitation. This hypothesis will have to be confirmed in further experiments. At $100 \mathrm{~kg} \mathrm{~m}^{-3}$, specific growth rate was $14 \%$ lower than at the second highest density $\left(70 \mathrm{~kg} \mathrm{~m}^{-3}\right)$.

Furthermore, blood parameters (except $\mathrm{CO}_{2}$ concentration), stress indicators (cortisol, proteinemia) and resistance to infection did not differ between density treatments, confirming that high density is not a chronic stress factor for sea bass.

This study confirms that fish can be reared under high densities in RAS without performance and welfare degradation, provided that the water quality is maintained above the safe levels for aquaculture. From the farmer's point of view, the stocking density limit can be established at approximately $70 \mathrm{~kg} \mathrm{~m}^{-3}$ to ensure a maximal specific growth rate of sea bass.

\section{Acknowledgements}

The authors would sincerely like to thank all the participants from the Ifremer Palavas station involved in the field experiment and also all the laboratory technicians for their contribution to the analyses. 


\section{References}

Alanärä, A., Brännäs, E., 1996. Dominance in demand-feeding behaviour in Arctic charr and rainbow trout: the effect of stocking density. Journal of Fish Biology, 48, 242-254.

Baker, R.F., Ayles, G.B., 1990. The effects of carrying density and loading level on the growth of Arctic charr (Salvelinus alpinus L.) and rainbow trout (Oncorhynchus mykiss). World Aquaculture, 21: 58-62.

Barton, B. A., Ribas, L., Acerete, L.,Tort, L., 2005. Effects of chronic confinement on physiological responses of juvenile gilthead sea bream, Sparus aurata L., to acute handling. Aquaculture Research,36, 2, 172-179.

Bayir, A., Necdet Sirkecioğlu, A., Polat, H., N., Aras, M., 2007. Biochemical profile of blood serum of siraz (Capoeta capoeta umbla). Comp. Clin. Pathol ., 16, 119-126.

Blancheton, J.P., 2000. Developments in recirculation systems for Mediterranean fish species. Aquacultural Engineering, 22, 17-31.

Canario, A.V.M., Condeça, J., Power, D.M., Ingleton, P.M., 1998. The effect of stocking density on growth in the gilthead sea-bream, Sparus aurata (L.). Aquaculture Research, 29, 177-181.

Chandroo, K.P., Duncan, I.J.H., Moccia, R.D., 2004. Can fish suffer?: perspectives on sentience, pain, fear and stress. Applied Animal Behaviour Science, 86, 225-250.

Coeurdacier, J.L., Dutto., G., 1999. Effect of chronic exposure to ammonia on alterations of proteins and immunoglobulins in sea bass (Dicentrarchus labrax L.,1758) serum. Aquatic Living Resources, 12, 247-253.

Coeurdacier, J. L, Laporte, F., Pépin, J.F. 2003. Preliminary approach to find synthetic peptides from nodavirus capsid potentially protective against sea bass viral encephalopathy and retinopathy. Fish \& Shellfish Immunology (2003) 14, 435-447.

Colt, J., 2006. Water quality requirements for reuse systems. Aquacultural Engineering, 34, 143-156.

Di Marco, P., Priori, A., Finoia, M.G., Mandich, A., Marino, G., 2003. Effects of an acute stress challenge on physiological stress response of the sea bass Dicentrarchus labrax at different stocking densities. International Aquaculture Conference Fish Farming in Mediterranean Europe: Quality for developing markets. Verona, 15-16 Ottobre 2003. Book of Abstracts p. 65.

Di Marco, P., Priori, A., Finora M.G., Massari A., Mandich, A., Marino, G., 2008. Physiological responses of European sea bass Dicentrarchus labrax to different stocking densities and acute stress challenge. Aquaculture 275, 319-328.

Ellis, T., North, B., Scott, A.P., Bromage, N.R., Porter, M., Gadd, D., 2002. The relationships between stocking density and welfare in farmed rainbow trout. Journal of Fish Biology, 61,3, 493-531.

Fivelstad, S., Schwarz, J., Strømsnes, H., Olsen, A.B. 1995. Sublethal effects and safe levels of ammonia in seawater for Atlantic salmon postsmolts (Salmo salar L.). Aquacultural Engineering, 14, 271-280.

Fivelstad, S., Haavik, H., Løvik, G., Olsen, A.B., 1998. Sublethal effects and safe levels of carbon dioxide in seawater for Atlantic salmon postsmolts (Salmo salar L.): ion regulation and growth. Aquaculture, 160, 305-316.

Iguchi, K., Ogawa, K., Nagae, M., Ito, F., 2003. The influence of rearing density on stress response and disease susceptibility of ayu (Plecoglossus altivelis). Aquaculture,220,1-4, 515-523.

Irwin, S., O'Halloran, J., FitzGerald, R.D., 1999. Stocking density, growth and growth variation in juvenile turbot, Scophthalmus maximus (Rafinesque). Aquaculture, 178, 7788.

Jeney, G., Galeotti, M., Volpatti, D., Jeney, Z., Anderson, D.P., 1997. Prevention of stress in rainbow trout (Oncorhynchus mykiss) fed diets containing different doses of glucan. Aquaculture, 154, 1-15 
Jørgensen,E.H., Christiansen, J.S., Jobling, M., 1993. Effects of stocking density on food intake, growth performance and oxygen consumption in Artic charr (Salvelinus alpinus). Aquaculture,110, 191-204.

Kjartansson, H., Fivelstad, S., Thomassen, J.M., Smith, M.J., 1988. Effects of different stocking densities on physiological parameters and growth of adult Atlantic salmon (Salmo salar L.) reared in circular tanks. Aquaculture 73, 1-4, 261-274.

Kristiansen, T.S., Fernö, A., Holm, J.C., Privitera, L., Bakke, S., Fosseidengen, J.E., 2004. Swimming behaviour as an indicator of low growth rate and impaired welfare in Atlantic halibut (Hippoglossus hippoglossus L.) reared at three stocking densities. Aquaculture, 230, 137-151.

Lambert, Y., Dutil, J.D., 2001. Food intake and growth of adult Atlantic cod (Gadus morhua $L$.) reared under different conditions of stocking density, feeding frequency and size-grading. Aquaculture, 192, 233-247.

Lefrançois, C., Claireaux, G., Mercier, C., Aubin, J., 2001. Effect of density on the routine metabolic expenditure of farmed rainbow trout (Oncorhynchus mykiss). Aquaculture, 195, 269-277.

Lemarié, G., Dosdat, A., Covès, D., Dutto, G., Gasset, E., Person-Le Ruyet, J., 2004. Effect of chronic ammonia exposure on growth of European seabass (Dicentrarchus labrax) juveniles. Aquaculture, 229,1-4, 479-491.

Magnadóttir, B., Jónsdóttir, H., Helgason, S., Björnsson, B., Jørgensen, T.Ø., Pilström, L., 1999. Humoral immune parameters in Atlantic cod (Gadus morhua L.) I. The effects of environmental temperature. Comparative Biochemistry and Physiology Part B: Biochemistry and Molecular Biology 122, 2, 173-180

Marino, G., Di Marco, P., Mandich, A., Priori, A., Finoia, M.G., Caudatella, S., 2001. Change in serum cortisol, metabolites, osmotic pressare and electrolytes in response to different blood sampling procedures in cultured sea bass (Dicentrarchus labrax L.). Journal of Applied Ichthyology, 17, 115-120.

Mazur, C.F., Iwama, G.K., 1993. Effect of handling and stocking density on hematocrit, plasma cortisol, and survival in wild and hatchery-reared chinook salmon (Oncorhynchus tshawytscha). Aquaculture,112,4, 291-299.

Montero, D., Izquierdo, M.S., Tort, L., Robaina, L., Vergara, J.M., 1999. High stocking density produces crowding stress altering some physiological and biochemical parameters in gilthead seabream, Sparus aurata, juveniles. Fish Physiology and Biochemistry, 20,1, 53-60.

Papoutsoglou, S.E., Tziha, G., Vrettos, X., Athanasiou, A., 1998. Effects of stocking density on behavior and growth rate of European sea bass (Dicentrarchus labrax) juveniles reared in a closed circulated system. Aquacultural Engineering, 18, 135-144.

Person-Le Ruyet, J., Galland, R., Roux, A., Chartois, H., 1997. Chronic ammonia toxicity to juvenile turbot (Scophthalmus maximus). Aquaculture, 154, 155-171.

Person-Le Ruyet, J., Mahe, K., Le Bayon, N., Le Delliou, H., 2004. Effects of temperature on growth and metabolism in a Mediterranean population of European sea bass, Dicentrarchus labrax. Aquaculture, 237, 269-280.

Petit, G., Beauchaud, M., Buisson, B., 2001. Density effects on food intake and growth of largemouth bass (Micropterus salmoïdes). Short communication. Aquaculture Research, 32, 495-497.

Pickering, A.D., 1992. Rainbow trout husbandry: management of the stress response. Aquaculture, 100, 125-139.

Pickering, A.D., Pottinger, T.G., Carragher, J.F., 1989. Differences in the sensitivity of brown trout, Salmo trutta L., and Rainbow trout, Salmo gairdneri Richardson, to physiological doses of cortisol. Journal of Fish Biology, 34, 5, 757-763.

Pierce, R.H, Weeks, J.M., Prappas, J.M., 1993. Nitrate toxicity to five species of marine fish. Journal of World Aquaculture Society, 24, 1, 105-107.

Procarione, L.S., Barry, T.P., Malison, J.A, 1999. Effects of High Rearing Densities and Loading Rates on the Growth and Stress Responses of Juvenile Rainbow Trout. NorthAmerican Journal of Aquaculture, 61, 2, 91-96. 
Roche, H., Bogé, G., 2000. In vivo effects of phenolic compounds on blood parameters of a marine fish (Dicentrarchus labrax). Comparative Biochemistry and Physiology, 125, 345-353.

Roncarati, A., Melotti, P., Dees, A., Mordenti, O., Angellotti, L., 2006. Welfare status of cultured seabass (Dicentrarchus labrax L.) and seabream (Sparus aurata L.) assessed by blood parameters and tissue characteristics. J. Appl. Ichthyol. 22, 225-234.

Rotlant, J., Ruane, N.M., Caballero, M.J., Montero, D., Tort, L., 2003. Response to confinement in sea bass (Dicentrarchus labrax) is characterised by an increased biosynthetic capacity of interrenal tissue with no effect on ACTH sensitivity. Comparative Biochemistry and Physiology , 136, 3, 613-620.

Rowland, S.J., Mifsud, C., Nixon, M., Boyd, P., 2005. Effects of stocking density on the performance of the Australian freshwater silver perch (Bidyanus bidyanus) in cages. Aquaculture, 253, 301-308.

Schram, E., Van der Heul, J.W., Kamstra, A., Verdegem, M.C.J., 2005. Stocking densitydependent growth of Dover sole (Solea solea). Aquaculture, 252, 339-347.

Schreck, C.B., Olla, B.L., Davis, M.W., 1997. In Cooke, S.J., Chandroo, K.P., Beddow, T.A., Moccia, R.D., Mc Kinley, R.S., 2000. Swimming activity and energetic expenditure of captive rainbow trout Oncorhynchus mykiss (Walbaum) estimated by electromyogram telemetry. Aquaculture Research, 31, 495-505.

Sørum, U., Damsgård, B., 2004. Effects of anaesthetisation and vaccination on feed intake and growth in Atlantic salmon (Salmo salar L.). Aquaculture, 232, 333-341.

Turnbull, J., Bell, A., Adams, C., Bron, J., Huntingford, F., 2005. Stocking density and welfare of cage farmed Atlantic salmon: application of a multivariate analysis. Aquaculture 243, 121-132.

Varsamos, S., Flik, G., Pepin, J.F., Wendelaar Bonga, S.E., Breuil, G., 2006. Husbandry stress during early life stages affects the stress response and health status of juvenile sea bass, Dicentrarchus labrax. Fish Shellfish Immunol., 20, 83-96.

Vijayan, M.M., Leatherland, J.F., 1988. Effect of stocking density on the growth and stress-response in brook charr, Salvelinus fontinalis. Aquaculture, 75, 1-2, 159-170.

Wallace, J.C., Kolbeinshavn, A.G., Reinsnes, T.G., 1988. The effects of stocking density on early growth in Artic charr, Salvelinus alpinus (L.). Aquaculture, 73, 101-110.

Wedemeyer, G.A., 1997. Effects of rearing conditions on the health and physiological quality of fish in intensive culture. In: Iwama, G.K., Pickering, A.D., Sumpter, J.P., Schreck, C.B. (Eds.), Society for Experimental Biology Seminar Series, vol. 62. Cambridge University Press, Cambridge, U.K., pp. 35-71.

Wendelaar Bonga, S.E., 1997. The stress response in fish. Physiol. Rev. 77, 591-625

Zoccarato, I., Benatti, G., Bianchini, M.L., Boccignone, M., Conti, A., Napolitano, R., Palmegiano, G.B., 1994. Differences in performance, flesh composition and water output quality in relation to density and feeding level in rainbow trout, Oncorhynchus mykiss (Walbaum). Farming Aquacult. Fish. Manag., 25, 239-647.

\section{Tables}

Table 1. Incoming water flows according to fish densities

\begin{tabular}{lllll}
\hline Density & $\begin{array}{l}\text { Saturated } \\
\text { water flow }\end{array}$ & $\begin{array}{l}\text { Super-oxygenated } \\
\text { water flow }\end{array}$ & \multicolumn{2}{l}{ Total water flow } \\
\hline $\mathrm{kg} \mathrm{m}^{-3}$ & $\mathrm{~m}^{3} \mathrm{~h}^{-1}$ & $\mathrm{~m}^{3} \mathrm{~h}^{-1}$ & $\mathrm{~m}^{3} \mathrm{~h}^{-1}$ & $\mathrm{~L} \mathrm{~kg}^{-1}$ of biomass h \\
\hline 10 & 0.35 & 0.15 & 0.5 & 50 \\
40 & 0.35 & 0.65 & 1 & 25 \\
70 & 0.55 & 1.2 & 1.75 & 25 \\
100 & 0.7 & 1.8 & 2.5 & 25 \\
\hline
\end{tabular}


Table 2. Rearing water characteristics measured during the 63 day experiment according to the density $\left(10,40,70\right.$ and $\left.100 \mathrm{~kg} \mathrm{~m}^{-3}\right)$; results are presented as mean \pm SD. Means in the same line not sharing a common letter were significantly different $(P<0.001)$.

\begin{tabular}{|c|c|c|c|c|}
\hline \multirow{2}{*}{ Water quality parameters } & \multicolumn{4}{|c|}{ Density $\left(\mathrm{kg} \mathrm{m}^{-3}\right)$} \\
\hline & 10 & 40 & 70 & 100 \\
\hline $\mathrm{pH}$ & $7.23 \pm 0.22 a$ & $7.05 \pm 0.23 c$ & $7.03 \pm 0.23 c$ & $7.02 \pm 0.23 c$ \\
\hline $\mathrm{CO}_{2}\left(\mathrm{mg} \mathrm{l}^{-1}\right)$ & $7.3 \pm 2.6 a$ & $12.7 \pm 3.7 c$ & $13.6 \pm 4.8 c$ & $13.0 \pm 5.1 c$ \\
\hline TAN $\left(\mathrm{mg} \mathrm{l}^{-1}\right)$ & $1.03 \pm 0.48 a$ & $1.44 \pm 0.43 c$ & $1.53 \pm 0.39 c$ & $1.57 \pm 0.43 c$ \\
\hline $\mathrm{NO}_{2}-\mathrm{N}\left(\mathrm{mg} \mathrm{l}^{-1}\right)$ & $1.55 \pm 0.75 a$ & $1.48 \pm 0.75 c$ & $1.46 \pm 0.74 c$ & $1.46 \pm 0.73 c$ \\
\hline $\mathrm{NO}_{3}-\mathrm{N}\left(\mathrm{mg} \mathrm{l}^{-1}\right)$ & $\begin{array}{l}12.60 \\
3.43 a\end{array} \quad \pm$ & $\begin{array}{l}12.60 \\
3.48 a\end{array}$ & $\begin{array}{l}12.42 \\
3.25 a\end{array} \quad \pm$ & $\begin{array}{l}12.37 \\
3.30 \mathrm{a}\end{array}$ \\
\hline $\mathrm{PO}_{4}-\mathrm{P}\left(\mathrm{mg} \mathrm{l}^{-1}\right)$ & $1.24 \pm 0.38 a$ & $1.25 \pm 0.37 a$ & $1.25 \pm 0.37 a$ & $1.23 \pm 0.37 a$ \\
\hline
\end{tabular}

Table 3. Blood parameters after a 63 day exposure to different fish densities (10, 40 and $100 \mathrm{~kg} \mathrm{~m}^{-3}$ ) in a recirculating system. Means in the same line not sharing a common letter were significantly different $(p<0.05)$.

\begin{tabular}{|c|c|c|c|}
\hline & \multicolumn{3}{|c|}{ Stocking density treatment $\left(\mathrm{kg} \mathrm{m}^{-3}\right)$} \\
\hline & $10 \mathrm{~kg} \mathrm{~m}^{-3}$ & $40 \mathrm{~kg} \mathrm{~m}^{-3}$ & $100 \mathrm{~kg} \mathrm{~m}^{-3}$ \\
\hline $\mathrm{Na}\left(\mathrm{mmol} \mathrm{I}^{-1}\right)$ & $161 \pm 7.1 \mathrm{a}$ & $158 \pm 6.6 a$ & $159 \pm 43.8 \mathrm{a}$ \\
\hline $\left.\mathrm{K}(\mathrm{mmol} \mathrm{I})^{-1}\right)$ & $6.4 \pm 0.8 \mathrm{a}$ & $6.6 \pm 0.4 a$ & $6.5 \pm 0.4 a$ \\
\hline $\mathrm{T} \mathrm{CO}_{2}\left(\mathrm{mmol} \mathrm{l}^{-1}\right)$ & $15.2 \pm 2.5 \mathrm{a}$ & $20.8 \pm 1.3 b$ & $20.6 \pm 1.7 b$ \\
\hline $\mathrm{PCO}_{2}(\mathrm{~mm} \mathrm{Hg})$ & $30.3 \pm 3.1 \mathrm{a}$ & $43.2 \pm 4.0 \mathrm{~b}$ & $43.8 \pm 5.1 b$ \\
\hline $\mathrm{HCO}_{3}\left(\mathrm{mmol} \mathrm{l}^{-1}\right)$ & $14.3 \pm 2.5 a$ & $19.4 \pm 1.2 b$ & $19.6 \pm 1.7 \mathrm{~b}$ \\
\hline $\mathrm{pH}$ & $7.3 \pm 0.106 a$ & $7.4 \pm 0.105 a$ & $7.4 \pm 0.104 a$ \\
\hline Glucose $\left(\mathrm{mg} \mathrm{l}^{-1}\right)$ & $81 \pm 25 a$ & $77 \pm 15 a$ & $84 \pm 22 a$ \\
\hline Hct (\% pcv) & $22 \pm 3 a$ & $21 \pm 3 a$ & $21 \pm 3 a$ \\
\hline
\end{tabular}

Figures 

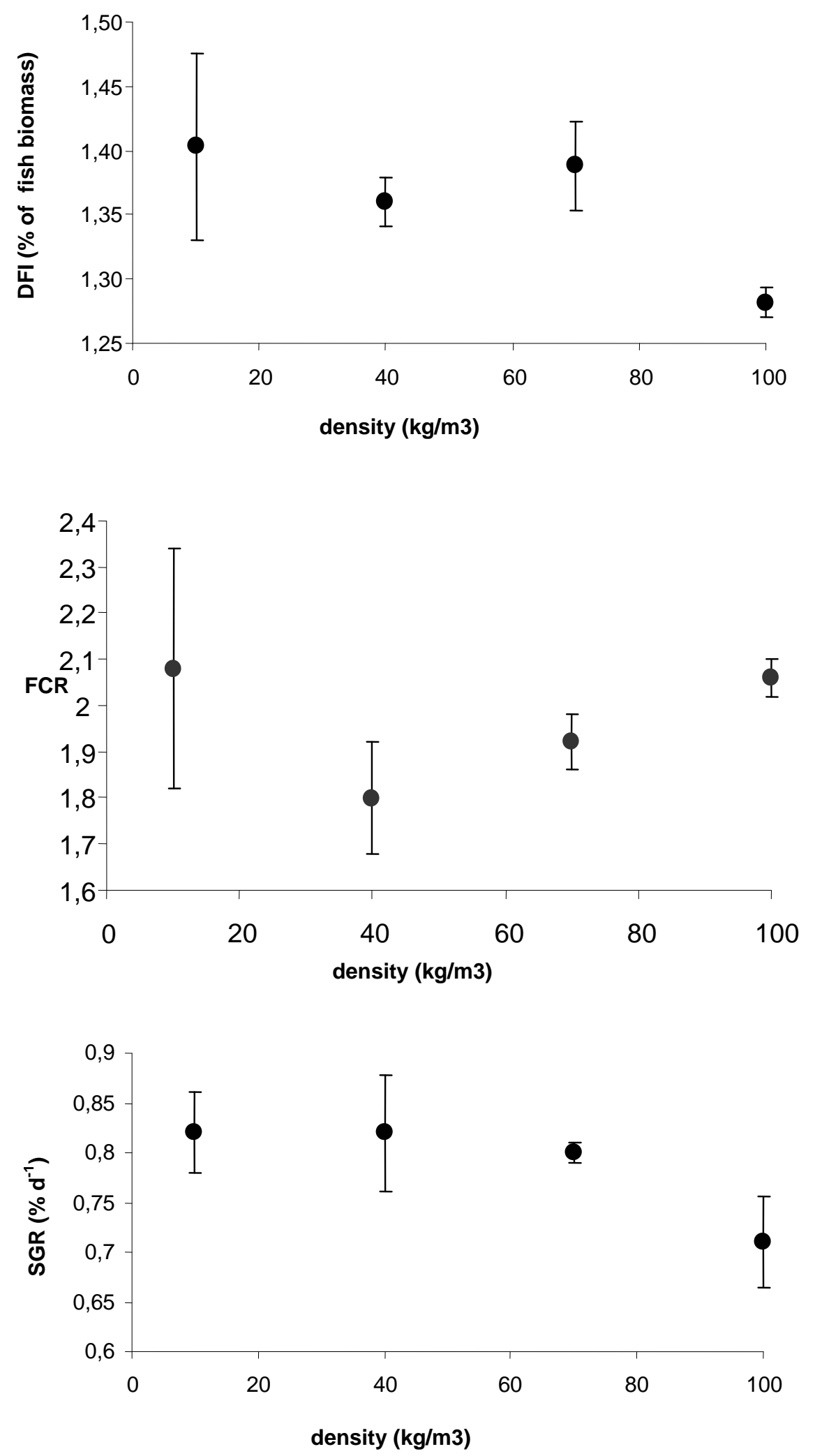

Fig.1. Daily feed intake (DFI, \%), feed conversion ratio (FCR) and specific growth rate $\left(\mathrm{SGR}, \% \mathrm{~d}^{-1}\right)$ (means \pm S.D.) of sea bass reared at 4 different densities $(10,40,70,100 \mathrm{~kg}$ $\mathrm{m}^{-3}$ ) during the 63-day experiment. 


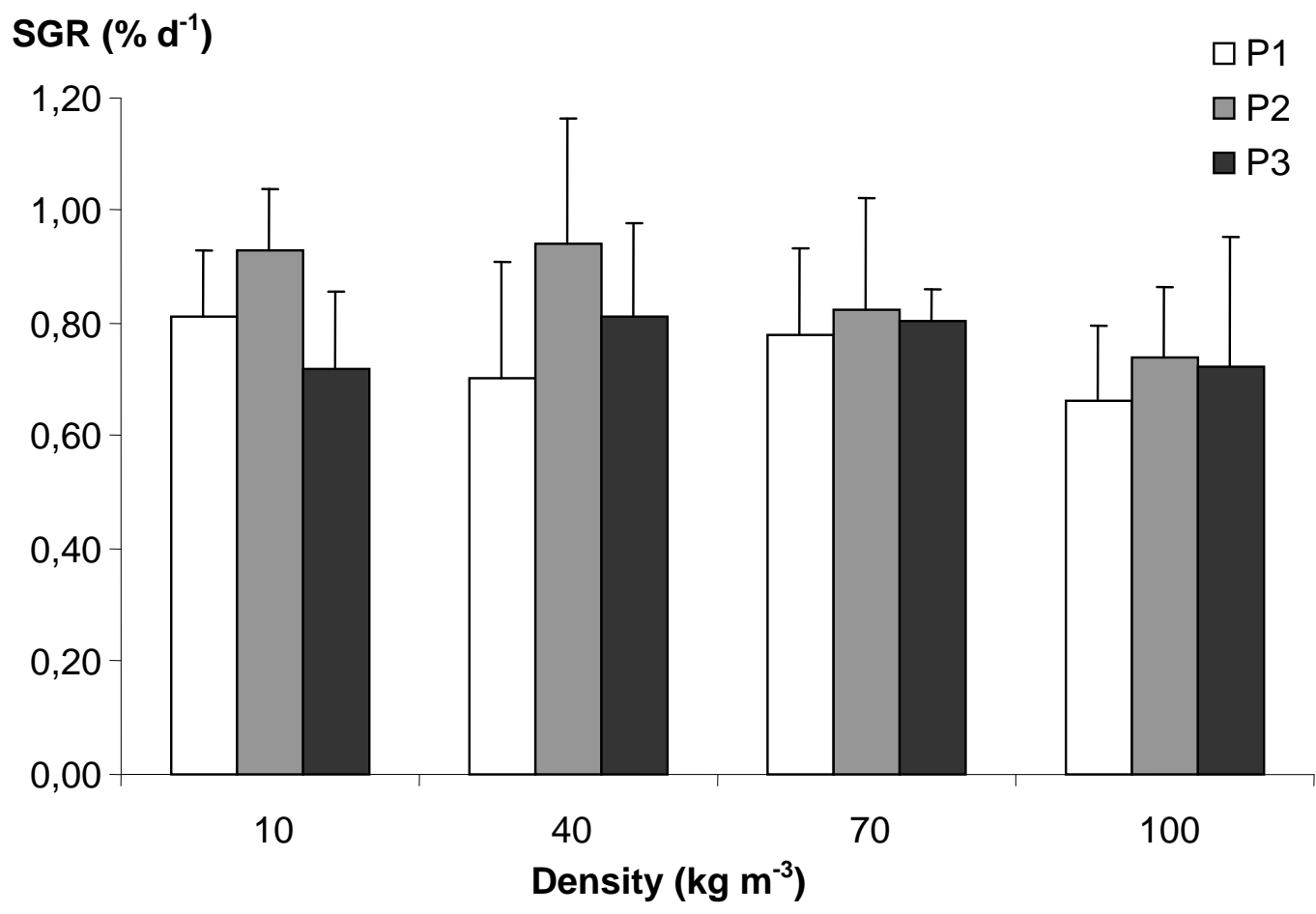

Fig.2. Specific growth rate (SGR, $\% \mathrm{~d}^{-1}$ ) of sea bass stocked at densities of $10,40,70$, $100 \mathrm{~kg} \mathrm{~m}^{-3}$ in tank based recirculating aquaculture system for three 21-day periods (P1, P2, P3).

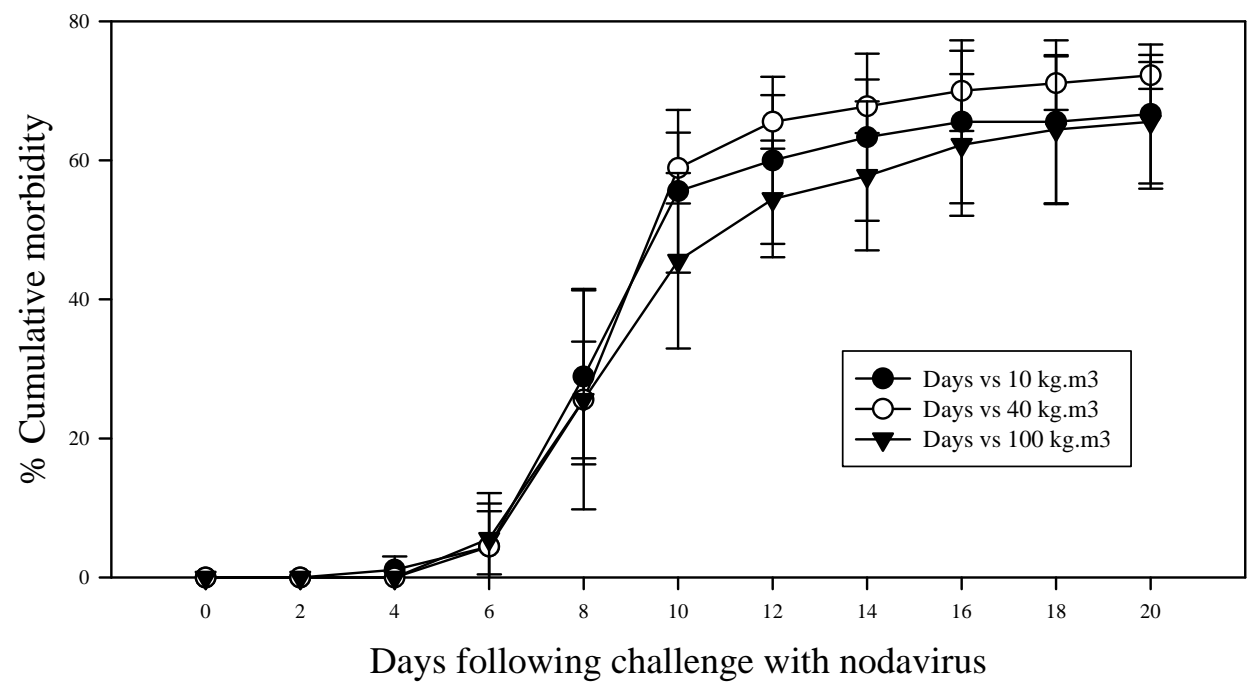

Fig.3. Cumulative morbidity (mortality and fish showing nervous symptoms) following nodavirus challenge on fish from 3 different densities $\left(10,40\right.$ and $\left.100 \mathrm{~kg} \mathrm{~m}^{3}\right)$. 


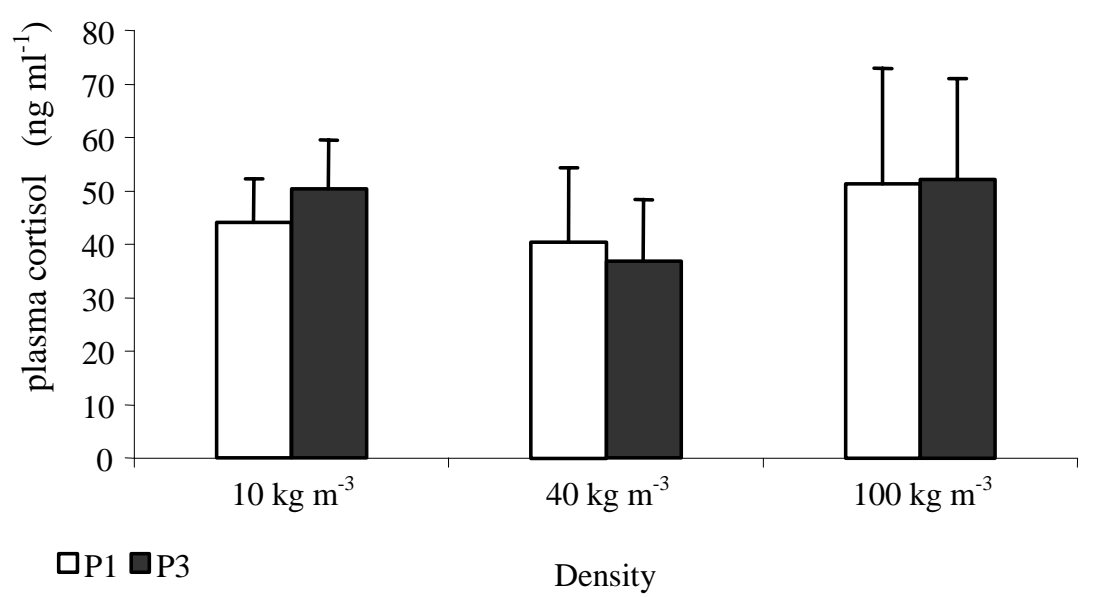

Fig. 4. Plasma cortisol concentrations (mean \pm S.E.M) of sea bass at three densities (kg $\mathrm{m}^{-3}$ ) at the end of the first (P1, 21 day) and the third period (P3, 63 days).

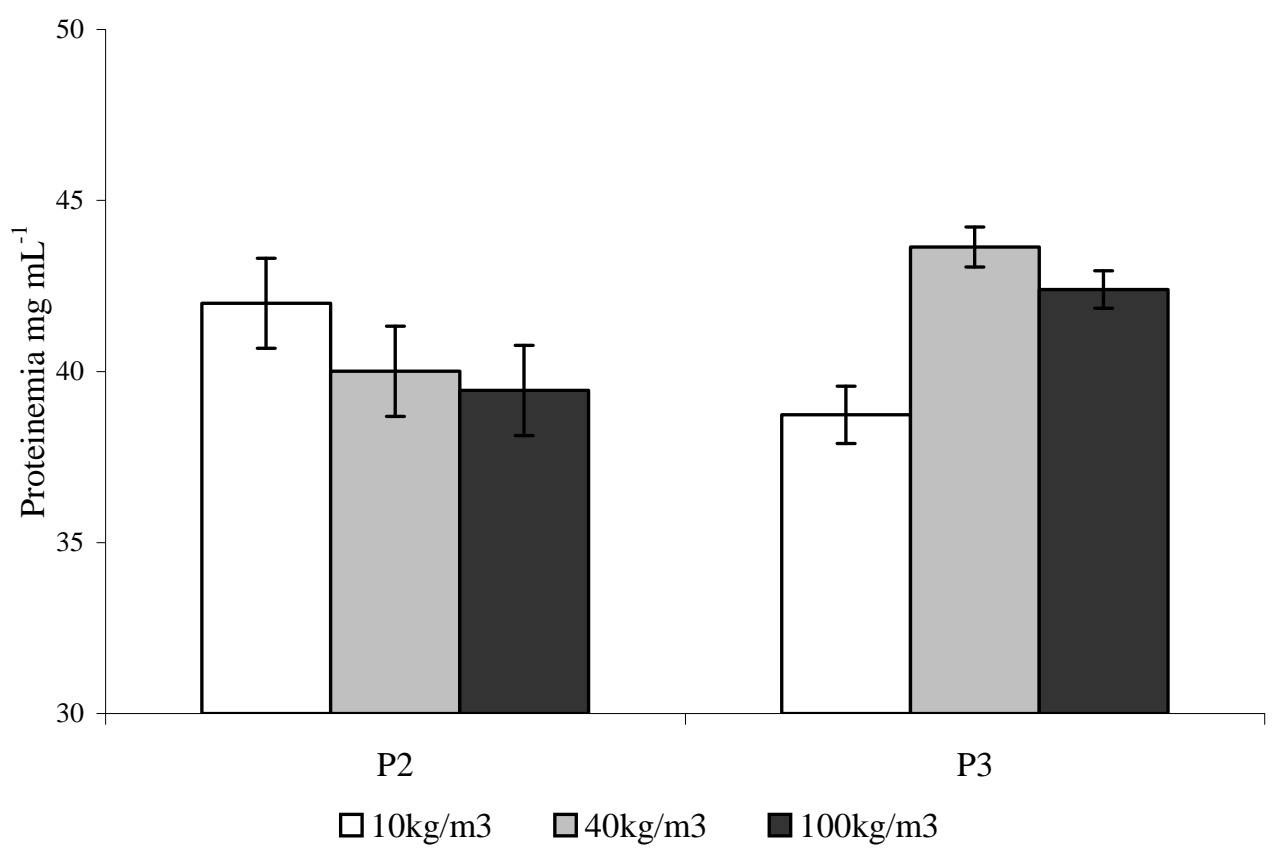

Fig. 5. Serum protein concentrations (mean \pm S.D.) of sea bass at three densities $\left(\mathrm{kg} \mathrm{m}^{-3}\right)$ at the end of the second (P2) and third periods (P3). 